\title{
LACAN DAN CERMIN HASRAT 'AKU' LIRIK DALAM KUMPULAN SAJAK AKU INI BINATANG JALANG KARYA CHAIRIL ANWAR
}

\author{
Lastry Monika \\ Universitas Gadjah Mada \\ lastry.monika@yahoo.com
}

Artikel diterima: 01 Juni 2020

Artikel direvisi: 13 Juli 2020

Artikel disetujui: 26 Agustus 2020

\begin{abstract}
Abstrak
Pembahasan dalam tulisan ini bertujuan untuk mengungkapkan cermin hasrat 'aku' lirik yang terdapat dalam kumpulan sajak Aku Ini Binatang Jalang karya Chairil Anwar. Pembahasan dalam hal ini mengacu pada mekanisme pembentukan subjek 'aku' lirik, ketaksadaran, dan cermin hasrat 'aku' lirik yang terdapat dalam beberapa puisi. Penelitian ini menggunakan perspektif dan metode psikoanalisis yang dikemukakan oleh Jacques Lacan. Analisis dalam hal ini dilakukan berdasarkan data-data yang diperoleh melalui kata, frasa, bait, dan larik yang terdapat dalam puisi untuk menemukan subjek, ketaksadaran, dan cermin hasrat 'aku' lirik sebagai upaya menemukan keutuhan diri melalui mekanisme metafora dan metonimia. Hasil dari pembahasan ini menunjukkan bahwa 'aku' lirik memiliki kecenderungan hasrat yang bertumpu pada kebebasan dan individualitas. Ketika 'aku' lirik menyadari diri berada pada tatanan yang tidak sesuai dengan yang ia kehendaki, 'aku' cenderung merasakan ketidakpuasan, ketakutan, dan kesepian sehingga 'aku' lirik mengonstruksi diri menjadi individu yang bebas, mandiri, dan tidak terikat dalam membangun identifikasi tentang
\end{abstract}

\begin{abstract}
The discussion in this paper aims to reveal a mirror of the desire "I" lyrics contained in the collection of poems Aku Ini Binatang Balang by Chairil Anwar. The discussion refers to the mechanism forming the subject "I" lyrics, unconsciousness, and mirrors the desire of "I" lyrics contained in several poems. This study uses the perspective and psychoanalysis method proposed by Lacan. The analysis in this case is based on data obtained through words, phrases, stanzas and arrays contained in poetry to find the subject, unconsciousness, and mirror of the desire to "me" the lyrics as an effort to find wholeness through metaphorical and metonemical mechanisms. The results of this discussion indicate that the "I" lyrics have a tendency to desire on freedom and individuality. When "I" lyrics realize that they are in a setting that is not what they want, "I" tends to feel dissatisfaction, fear, and loneliness so that "I" lyrics construct themselves into free, independent, and unrestricted individuals in building identification about himself.
\end{abstract}

Keywords: Lacan, mirror of passion, poetry

\section{Pendahuluan}

H.B. Jassin memberikan pemahaman bahwa pembagian angkatan dalam kesusastraan Indonesia diperlukan dikarenakan beberapa hal. Di antara hal-hal tersebut ialah adanya polemik, perbedaan atau pertentangan pendapat, perbedaan visi atau perlainan konsepsi, atau pun sekadar untuk keperluan administrasi. Saat ini, pendapat H.B. Jassin tersebut salah satunya juga diperlukan bagi para peneliti atau analis bidang humaniora-terkhusus di bidang 
sastra-dalam menentukan fokus objek penelitian terhadap salah satu dari beberapa pembagian angkatan atau periodisasi kesusastraan Indonesia tersebut.

Salah satu periode yang cukup menonjol dan tergolong penting dalam sejarah kesusastraan Indonesia ialah Angkatan 45. Ajip Rosidi dalam Ikhtisar Sejarah Sastra Indonesia (Rosidi, 2018) menggolongkan periode ini sebagai periode "perkembangan" -setelah periode "kelahiran" kesusastraan modern Indonesia yang menurutnya dimulai pada Angkatan Pujangga Baru.

Beberapa kritikus beranggapan bahwa Angkatan Pujangga Baru identik dengan romantisisme. Memasuki masa kedudukan Jepang, karya-karya sastra pada saat itu mulai berubah arah menjadi identik dengan realisme, akan tetapi sisi yang tidak dilupakan antara keduanya ialah menyuarakan nasionalisme. Selain itu, isi kesusastraan sesudah perang kemudian lebih identik dengan kehidupan itu sendiri. Ketika itu (setelah kemerdekaan) berdiri Gelanggang 1946 yang pada akhirnya membawa pada lahirnya angkatan baru, yaitu angkatan sesudah perang atau Angkatan 45.

Bagian yang menjadi penting mengenai Angkatan 45 ialah adanya manifesto "Surat Kepercayaan Gelanggang" yang diprakarsai oleh Asrul Sani dan Usmar Ismail. Manifesto ini terbit dari himpunan pengarang yang tergabung dalam Gelanggang Seniman Merdeka-semacam organisasi yang menghimpun berbagai pegiat seni yang berdiri pada tahun 1946. Manifesto ini dapat dikatakan sebagai arah semangat nasionalisme setelah pra-kemerdekaan. Semangat tersebut di antaranya meliputi tiga hal, 1) penolakan terhadap kecenderungan untuk mengawetkan warisan masa lalu hanya karena kenyataan akan kesempatan menjadi Indonesia; 2) revolusi belum selesai; dan 3) ikatan antara seniman dan masyarakat.

Pandangan lain mengenai manifesto Surat Kepercayaan Gelanggang ialah datang dari Meier yang mencatat 5 gagasan pokok mengenai manifesto tersebut. Di antaranya, 1) revolusi belum selesai; 2) universalisme; 3) humanisme; 4) hubungan antara seniman dan masyarakat; dan 5) tuntutan akan kebebasan dan toleransi. Dari kedua pandangan tersebut dapat disimpulkan bahwa manifesto Gelanggang sebetulnya dapat memiliki penafsiran yang terbuka, namun yang disepakati oleh para pengamatnya ialah 'universalisme' (Chisaan, 2008).

Angkatan 45 juga disebut dengan berbagai sebutan lain, di antaranya Angkatan Chairil Anwar dan Angkatan Kemerdekaan. Salah satu penyair yang digadang-gadang sebagai pembawa kebaruan dalam angkatan ini ialah Chairil Anwar. Sajak-sajaknya dianggap bernilai baru. Bahasa yang digunakan dalam sajaksajaknya ialah dominan bahasa sehari-hari, namun dinilai tetap bernilai sastra. Menurut H.B Jassin (Jassin, 1985), Chairil Anwar merupakan penyair yang paling individualis pada masanya. Ia membawa udara segar ke dalam kesusastraan Indonesia dengan sajaksajaknya yang revolusioner.

Berkaitan dengan kepenyairan Chairil Anwar, Abdul Hadi W.M. dalam majalah Horison mengatakan bahwa yang menarik dari Chairil ialah vitalitasnya sebagai penyair, semangat kepenyairannya yang tidak mengenal politik 'daging sapi'. Ia mau berkorban dan menderita demi cita-cita kepenyairannya yang menyatu dalam dirinya. Selepas kepergiannya, melalui sajak-sajaknya, Chairil mengekalkan imaji dirinya selaku pemberontak terhadap adatistiadat, nilai, dan kemapanan Pujangga Baru. Ia seolah menegaskan ungkapan dalam sajaknya "Diponegoro": sekali berarti, sudah itu mati (Suyono, 2016).

Jassin dalam (Maier, 1987), juga mengatakan bahwa Chairil Anwar merupakan penyair yang membawa terobosan radikal 
dalam sastra Indonesia. Ia dianggap sebagai inovator yang membuka pemandangan baru terhadap sastra Indonesia berdasarkan ambiguitas ekspresi dan isi bahasa yang ringkas dan padat. Adapun isi dalam puisipuisinya cenderung menyuarakan opini menyimpang yang di dalamnya terdapat kesepian, ketakutan, serta gagasan antifasisme dan anti-kolonial dengan mengemukakan perasaan pribadi. Ia dianggap sebagai pelopor Angkatan 45. Jassin kemudian juga mengatakan bahwa sajaksajaknya selain revolusioner dalam bentuk dan isi, serta membawa aliran Expressionism (Jassin, 1975). Oleh sebab itu, hal-hal yang sebelumnya dikatakan identik dengan karyakarya Angkatan 45-terkhusus dalam sajaksajak Chairil Anwar-akan dibahas dalam tulisan ini. Bagaimanakah visi atau konsepsi, tuntutan kebebasan, dan universalisme tergambar melalui sajak-sajaknya melalui cerminan hasrat yang muncul dalam puisipuisinya? Setidaknya demikianlah fokus permasalahan yang dibahas dalam tulisan ini.

Analisis dalam tulisan ini menggunakan teori pascastrukturalisme, yaitu berdasarkan perspektif psikoanalisis yang di kemukakan oleh Jacques Lacan. Secara tradisional, psikoanalisis diterapkan dalam literatur. Mengenai hal ini, Gallop mengutip pernyataan Lacan bahwa studi sastra memiliki peran sebagai dasar untuk psikoanalisis (Gallop, 1984). Gallop menambahkan bahwa melalui psikoanalisis, kritikus sastra mempelajari cara membaca teks dan menafsirkannya, bukan hanya membaca konten atau ide.

Psikoanalisis dianggap memiliki hubungan dengan psikologi klinis yang pada akhirnya memberi batasan antara ilmu pengetahuan dan ilmu-ilmu sosial, terlebih humaniora. Akan tetapi Lacan melanggar batasan tersebut dan menyatakan bahwa psikoanalisis sebagai ilmu, sehingga baginya tidak ada lagi perbedaan antara sains- humaniora. Kemudian mengenai psikoanalisis dan literatur, Felman dalam (Gallop, 1984) mengatakan bahwa teks memiliki otoritas dan otoritas tersebut digunakan oleh Lacan untuk mendefinisikan peran psikoanalisis dalam struktur pemindahan, seperti yang dilihat oleh pasien, teks tersebut dipandang oleh kritikus sebagai subjek yang dianggap tahu atau tempat di mana makna dan pengetahuan makna berada.

Kemudian, dengan menggunakan perspektif psikoanalisis, Faruk berpendapat bahwa hal itu berarti berusaha untuk menemukan kondisi bawah sadar yang dilingkupi oleh rasa kurang dan kehilangan yang menyertai hasrat untuk kesatuan diri (Faruk, 2012). Pemahaman terhadap sajaksajak Chairil Anwar dalam Aku Ini Binatang Jalang dalam hal ini diarahkan pada bahasa karya sastra dan bagaimana ia bergerak keluar dari dirinya berdasarkan fenomena metafora dan metonimi.

Perspektif Lacan sebagai bagian dari pascastrukturalisme memiliki beragam konsep tertentu. Bagi Lacan, ketidaksadaran merupakan suatu struktur yang tersembunyi yang menyerupai struktur bahasa (Faruk, 2012). Pengetahuan dan pandangan mengenai dunia, orang lain, diri, dan hal-hal lain yang melingkupinya ditentukan oleh bahasa. "Sayakamu" dalam hal ini mengarah pada subjek dengan oposisi timbal baliknya. Kemudian, hal itulah yang mendasari subjektivitas selain bahasa yang juga diadakan secara sosial dari kebudayaan dan hukum-hukum tertentu. Lebih lanjut dijelaskan bahwa "Saya" disebut dengan "tahap cermin" dikarenakan pada tahap ini terbentuk pengakuan diri.

Mengutip Dallmayr, selain dikatakan bahwa alam bawah sadar terstruktur seperti bahasa, subjek bagi Lacan juga hanya dapat beroperasi dalam bahasa dengan terusmenerus mengulangi saat pembagian mendasar dan tidak dapat direduksi. Dengan kata lain, subjek didasari dalam bahasa sebagai 
pembagian atau pemisahan (Dallmayr, 1989). Kemudian, pembagian atau pemisahan yang paling mendasar tidak hanya berkaitan dengan penanda dan objeknya, tetapi juga hubungan subjek dengan dirinya sendiri.

Lacan memperkenalkan Oedipus Kompleks yang di dalamnya seseorang menghumanisasikan dirinya menjadi dirinya sepenuhnya melalui beberapa tahap. Faruk menjelaskan bahwa resolusi Oedipus Kompleks membebaskan subjek dalam kesadarannya akan diri melalui partisipasi kebudayaan, bahasa, dan peradaban (Faruk, 2012). Lacan berpendapat bahwa ketidaksadaran sebanding dengan struktur bahasa. Dengan kata lain, bahasa baginya menciptakan dan memunculkan ketaksadaran. Oleh sebab itulah formasi ketaksadaran diatur oleh mekanisme metafora dan metonimi sebagaimana dalam bahasa. Metafora dimaksudkan sebagai penanda yang ditandakan untuk menghasilkan penanda baru, sedangkan metonimi dimaksudkan sebagai hubungan diakronis antara satu penanda dan penanda lainnya dalam satu rantai penandaan.

Berhubungan dengan penjelasan tersebut, Bracher berpendapat bahwa sebetulnya budaya memainkan suatu peranan tertentu di dalam suatu perubahan sosial atau dalam menolak perubahan (Bracher, 2009). Hal itu dilakukan dengan memanfaatkan hasrat dari subjek. Ia melanjutkan bahwa selama gejala kebudayaan ini berhasil menginterpelasi para subjek-mengajak mereka mengambil suatu disposisi subjektif-hal ini dilakukan dengan membangkitkan satu jenis hasrat atau menjanjikan dipuaskannya suatu hasrat tertentu. Oleh sebab itu, agar bisa dipahami bagaimana gejala kebudayaan memengaruhi manusia, yang menjadi titik perhatian dalam kritiknya ialah hasrat, bukan pengetahuan. Dalam hal ini intervensi dapat dilakukan dengan cara, pertama, memahami berbagai peranan dan bentuk hasrat yang ada dalam ekonomi subjek; kedua, memahami cara budaya bekerja pada dan melalui bentuk hasrat tersebut.

Lacan dalam (Bracher, 2009) merumuskan tiga landasan pembedaan mengenai hasrat. Pertama, 'hasrat' bisa berbentuk sebagai hasrat untuk menjadi atau hasrat untuk memiliki. Kedua, kata 'dari' dalam perumusan Lacan berfungsi sebagai genitif subjektif dan genitif objektif serta menunjukkan bahwa Liyan bisa menjadi subjek atau objek hasrat. Ketiga, 'Liyan' bisa berupa citra orang lain yang ada di dalam tatanan imajiner, atau kode yang membentuk tatanan simbolik.

Lacan kemudian juga mengemukakan empat kategori hasrat, yaitu (1) hasrat narsistik pasif, yaitu hasrat seseorang untuk menjadi objek cinta (kekaguman, pengakuan) dari Liyan; (2) hasrat narsistik aktif, yaitu hasrat seseorang untuk menjadi Liyanmenyatu dengan Liyan dengan identifikasiidentifikasi yang mana cinta dan pemujaan merupakan bentuk Liyan; (3) hasrat anaklitik pasif, yaitu hasrat seseorang untuk dimiliki Liyan sebagai objek dari sumber jouissance Liyan; dan (4) hasrat anaklitik aktif adalah hasrat seseorang untuk memiliki Liyan sebagai cara untuk mencapai jouissance (Bracher, 2009).

Penelitian terhadap kumpulan sajak Aku Ini Binatang Jalang karya Chairil Anwar belum pernah dilakukan menggunakan perspektif Lacanian. Akan tetapi, beberapa karya sastra prosa dan puisi di antaranya pernah diteliti menggunakan perspektif Lacan. Penelitian tersebut di antaranya "Hasrat Sartika Sari dalam Kumpulan Puisi Elegi Titi Gantung: Perspektif Lacanian" (2019) yang ditulis oleh Heny Anggreini dan Pujiharto (Heny \& Pujiharto, 2019). Penelitian ini membahas mengenai ke-diri-an subjek Sartika melalui hasratnya yang tersembunyi dan direpresi oleh nilai-nilai, hukum, dan budaya seperti yang terdapat dalam Elegi Titi Gantung. Hasil 
penelitian ini menunjukkan bahwa Sartika berhasrat untuk menjadi perempuan eksis dan menjadi perempuan idaman. Hasrat tersebut menunjukkan keberadaan dirinya sebagai subjek di tatanan simbolik dan menjadi perempuan idaman sebagai bentuk negosiasi Sartika pada dirinya yang menginginkan kebebasan.

Penelitian lain ialah "Hasrat Nano Riantiarno dalam Cermin Cinta: Kajian Psikoanalisis Lacan" (2016) yang ditulis oleh Ricky Aptifive Manik (Manik, 2016). Penelitian ini bertujuan untuk menemukan apa yang menjadi pembayangan ego-ego ideal bagi Nano. Penelitian tersebut menemukan bahwa hasrat menjadi penulis dan seniman menuntun Nano secara tidak sadar pada penanda-penanda simbolik lainnya seperti penulis yang pantang menyerah, ulet, konsisten, tekun, rajin, dan sebagainya. Nano mendapat citraan dari Rendra, Putu Wijaya, Arifin C. Noor, dan Teguh Karya sebagai hasratnya akan keutuhan yang ontologis bagi identitasnya. Dalam hal ini, kebebasan menjadi objek $a$ Nano untuk mendapatkan jouissance bagi dirinya.

Selain kedua penelitian tersebut, juga terdapat hasil penelitian lain yang berjudul "Psychosis and Mourning in Lacan's Hamlet" yang ditulis oleh John P. Muller (Muller, 1980). Ia menganalisis mengenai Hamlet berdasarkan teori psikoanalisis yang dikembangkan oleh Jacques Lacan. Tulisan yang ditulis oleh John P. Muller memfokuskan analisisnya terhadap Hamlet. Dalam artikelnya ia menyebutkan bahwa Lacan menanggapi bahwa hal tersebut merupakan tragedi Hamlet atau apa yang disebut dengan "The Tragedy Hamlet". Dalam hal ini Lacan membawa pembaca pada apa yang dirumuskannya mengenai objek petit $a$, phallus, dan penyitaan yang berakhir pada berkabung dan kematian.

Berdasarkan paparan tersebut, dua hasil penelitian sebelumnya cenderung menganalisis mengenai ke-diri-an subjek-dalam hal ini pengarang-melalui karya-karya yang diciptakan. Akan tetapi, pada tulisan ini cermin hasrat yang diteliti ialah melalui 'Aku' lirik yang terdapat dalam kumpulan sajak $A k u$ Ini Binatang Jalang. Hal itu didasarkan pada rumusan Lacan mengenai subjektivitas yang sepenuhnya relasional. Dengan kata lain, melalui oposisi antara "saya" dan "kamu". Dalam hal ini subjektivitas bukanlah esensi, melainkan seperangkat relasi. Oleh karena itu, puisi-puisi yang dianalisis dalam pembahasan ini ialah puisi-puisi yang memiliki sudut pandang 'aku' lirik.

Adapun metode yang digunakan dalam penelitian ini ialah berdasarkan metode psikoanalisis Lacan. Faruk berpendapat bahwa memahami karya sastra dengan perspektif Lacanian ialah sebuah usaha untuk menemukan kondisi bawah sadar yang dipenuhi oleh rasa kurang dan rasa kehilangan yang menyertai hasrat untuk kesatuan diri (Faruk, 2012). Dalam hal ini, pemahaman terhadap karya sastra-sebagaimana yang telah disinggung sebelumnya-diarahkan pada apa yang terjadi pada bahasa karya sastra itu. Metafora dalam perspektif Lacan ialah prinsip kondensasi yang di dalamnya terjadi penjajaran penanda-penanda sehingga terjadi pergeseran makna. Kemudian, metonimi bekerja dengan prinsip "pemlesetan" untuk mengalihkan perhatian sensor.

\section{Mekanisme Pembentukan Subjek 'Aku' Lirik dalam Kumpulan Sajak Aku Ini Binatang Jalang}

Lacan merumuskan bahwa subjektivitas sepenuhnya relasional. Dengan kata lain, melalui prinsip perbedaan dan melalui oposisi antara saya dan kamu. Maksudnya ialah, subjektivitas bukanlah esensi, melainkan seperangkat relasi (Faruk, 2012). Sebagai suatu elemen penting yang berhubungan dengan subjek, cermin menjadi sebuah entitas 
sekaligus citra yang problematis (Bracher, 2009). Ia memunculkan kisah orisinal dan efek pembacaan khusus serta sejalan dengan tahapan pembentukan subjek dalam psikoanalisis yang dirumuskan oleh Lacan. Dalam hal ini, cermin dan bahasa merupakan akar penyebab proses penemuan subjek. Tindakan bercermin dimulai dengan memeriksa tubuh, lalu dari tubuh tersebut dihasilkan identifikasi diri. Berhubungan dengan hal itu, identifikasi diri dalam karya sastra ialah melalui bahasa yang merupakan bagian dari 'tindakan bercermin' itu sendiri.

Sebagai bagian dari mekanismenya, Lacan membagi proses pembentukan subjek ke dalam tiga fase (Bracher, 2009). Fase pertama disebut dengan fase pra-Oedipal pada tatanan Real (the Real). Pada fase ini, seorang anak belum mengenal batasan ego atau dirinya. Ia dan ibunya merupakan kesatuan dan identifikasi diri belum terjadi pada fase ini. Fase kedua ialah fase cermin pada tatanan Imajiner (the Imaginary). Fase ini paling krusial dalam identifikasi dan perkembangan ego karena memisalkan seorang anak bercermin dan menjumpai identifikasi dirinya yang imajiner. Cermin merupakan pandangan ibunya. Dengan kata lain, anak melihat dirinya sebagaimana ibunya melihat dirinya-sebagai Liyansebelum ia melihat dirinya sendiri. Fase ketiga ialah fase Oedipal pada tatanan Simbolik (the Symbolic). Pada fase ini anak berpisah dengan ibu dan harus mengalami kastrasi. Ibu dipandang sebagai Liyan sebab tidak lagi dilihat sebagai satu-kesatuan dengan diri sang anak. Kemunculan 'ayah simbolik' memperparah hubungan antara ibu dan anak dan menyebabkan anak kehilangan objek hasratnya, yakni ibu (liyan).

Salah satu sajak yang cukup menonjol menampilkan hasrat dalam mengidentifikasi diri ialah dalam puisi berjudul "Aku". 'Aku' lirik dalam hal ini menggunakan hasrat dalam penemuan diri atau mengidentifikasi diri. Akan tetapi, eksistensi diri 'aku' tidak begitu saja tercapai dikarenakan dalam puisi tersebut ia tidak dapat pula dilepaskan dari bentuk lain seperti "kau" dan "kumpulan".

Proses penemuan diri pada 'aku' seperti telah melewati atau sedang berada pada fase kedua, yaitu fase Cermin atau tatanan imajiner. Sebagaimana yang telah dijelaskan sebelumnya, fase ini ialah fase yang krusial untuk identifikasi atau perkembangan ego. 'Aku' melewati tahap bercermin, lalu menemukan diri yang ada dalam cermin tersebut bersifat imajiner. Saat itu, ia mulai menciptakan suatu konstruksi bagi dirinya dan terus membuat identifikasi imajiner. Cermin dalam hal ini ialah pandangan ibunya, yaitu "kau" dan "kumpulan". Sebelumnya, 'aku' berpikir atau menganggap bahwa citra dirinya ialah yang sesungguhnya, sebagaimana pandangan dari "kau" dan "kumpulan".
Kalau sampai waktuku
'kumau tak seorang 'kan merayu
Tidak juga kau
Tak perlu sedan itu
Aku ini binatang jalang
Dari kumpulannya terbuang
(Anwar, 2011)

Larik pada puisi tersebut telah sampai pada fase ketiga dalam perkembangan atau penemuan diri bagi 'aku', yaitu fase yang disebut oleh Lacan sebagai fase Oedipal atau tatanan Simbolik. Pada fase ini, anak harus berpisah dari ibunya dan harus mengalami kastrasi. 'Aku' melepaskan diri dari satu kesatuan diri yang sebelumnya dibentuk oleh "kau" dan "kumpulan". Ia mengidentifikasi diri dengan menjadi sosok 'aku' sebagai subjek. Larik sebagaimana larik berikut memperkuat eksistensi diri 'aku' sebagai subjek.

Biar peluru menembus kulitku Aku tetap merajang menerjang 
Luka dan bisa kubawa berlari

Berlari

Hingga hilang pedih peri

Dan aku akan lebih tidak peduli

(Anwar, 2011)

Penemuan subjek berdasarkan perspektif Lacan tidak dapat dibebaskan dari bahasa. Hubungan antara subjek dengan bahasa memberikan arti bahwa subjek diwakili oleh bahasa melalui penandapenanda (Bracher, 2009). Kemudian, menurut Lacan tanda adalah apa yang mewakili subjek ke tanda lain (Pluth, 2006). Dalam definisi itu, hubungan subjek dengan bahasa dimasukkan dalam bentuk representasi. Kemudian Lacan menyatakan secara eksplisit bahwa penanda mewakili subjek. Penemuan subjek dalam hal ini menyebabkan konsekuensi tertentu, yaitu masuknya bahasa ke dalam subjek. Dalam hal ini, "kau" dan "kumpulan" dapat dikatakan sebagai konstruksi sosial tertentu, masyarakat atau kebudayaan yang ditentang, dilawan, atau yang tidak dikehendaki lagi oleh 'aku'. Identitas diri 'aku' melepaskan diri dari kemungkinan-kemungkinan tersebut karena dapat saja memberikan rasa kurang atau kehilangan sehingga perlu dilawan untuk menemukan kesatuan diri yang utuh, bebas, dan mandiri.

'Aku' lirik pada kutipan puisi sebelumnya dapat dikatakan terpaut dari tambatannya sendiri. Dengan kata lain terdapat keinginan yang pemenuhannya dilarang atau dihalangi. Larangan atau hambatan tersebut sebagaimana yang telah disinggung pada paragraf sebelumnya berkemungkinan berupa aturan-diatur, yaitu tatanan simbolik sebagai larangan normatif.

Penemuan subjek dalam kumpulan puisi Aku Ini Binatang Jalang dapat ditelusuri melalui puisi lain. Setiap puisi menghadirkan beragam penanda-penanda tertentu. Pada puisi yang berjudul "Kabar dari Laut", 'aku' mengalami proses negasi terhadap "kau" dan "mereka". Dalam puisi ini 'aku' mempertanyakan bagaimana "kau" dan "mereka" sebagaimana bait berikut.

Dan kau? Apakah kerjamu sembahyang dan memuji,

Atau di antara mereka juga terdampar,

Burung mati pagi hari di sisi sangkar?

(Anwar, 2011)

Selain itu, pada bait pertama, 'aku' menyadari suatu hal akan dirinya seperti yang terdapat pada bait berikut.

Aku memang benar tolol ketika itu, mau pula membikin hubungan dengan kau; lupa kelasi tiba-tiba bisa sendiri di laut pilu, berujuk kembali dengan tujuan biru.

(Anwar, 2011)

'Aku' menyadari diri sebagai subjek terbelah, merasa kurang, dan tidak utuh dengan ungkapan penyesalan melalui "Aku memang benar tolol ketika itu,". Bagi Lacan, dari konsep kekurangan serupa itu terdapat determinasi antara Yang Real dan Yang Simbolik. 'Aku' mencari kepastian diri walaupun pada bait tersebut mengacu kepada Yang Lain atau "kau". Melalui hal itu, 'aku' berusaha mengonstruksi diri terhadap realitas meskipun pada larik-larik berikutnya ia menyatakan "Di tubuhku ada luka sekarang,", "... lagi aku pun sangat lemah serta menyerah.", dan "... Aku di antara mereka juga terdampar,". 'Aku' lirik cenderung tampil sebagai subjek yang berani, hidup, dan menginginkan kebebasan berdasarkan penanda-penanda yang dihadirkan.

Berdasarkan penjelasan tersebut, terhadap 'aku' lirik terdapat penolakan internalisasi jiwa, baik pada tingkat imajiner maupun simbolik. Subjek mengalami dislokasi, di antaranya dapat berpartisipasi dalam serangkaian interaksi atau justru terbelah melawan dirinya sendiri. Mengutip penjelasan Dallmayr (Dallmayr, 1989), subjek menghasilkan keinginan yang 
Poetika : Jurnal Ilmu Sastra

Vol. 8 No. 1, Juli 2020
DOI 10.22146/poetika.56534

ISSN 2338-5383 (print) ; 2503-4642 (online) terus-menerus bahkan melampaui sumber daya alam biologis dan diskursif. Keinginan tersebut tidak dapat dibungkam dengan caracara yang murni alami atau bersifat diskursif.

\section{Ketaksadaran dan Bahasa dalam \\ Kumpulan Sajak Aku Ini Binatang Jalang}

Psikoanalisis Lacan mewartakan kabar bahwa seseorang bukan lagi pusat dari dirinya sendiri, karena ada subjek lain dalam dirinya, yaitu ketaksadaran (Bracher, 2009). Lacan mengatakan bahwa ketaksadaran merupakan sesuatu yang terstruktur seperti bahasa (Lacan, 1978). Hal ini dikarenakan bagi Lacan ketaksadaran merupakan wilayah dari hasrat manusia. Lacan juga mengemukakan bahwa manusia dewasa berada di antara sadar dan tak sadar (Bracher, 2009). Dalam hal ini, ketaksadaran lebih sering muncul. Ketaksadaran tersebut bagi Lacan, selain terstruktur seperti bahasa, mekanismenya juga serupa metafora dan metonimia. Lebih lanjut Lacan mengatakan bahwa ketaksadaran terbentuk bersamaan dengan bahasa. Ia hadir sebagai hasil dari penstrukturan hasrat oleh bahasa. Kemudian, hasrat memiliki peran penting yang telah memberikan gambaran pada ketaksadaran.

Lacan menjelaskan bahwa subjek yang telah merepresi kebenaran bukan penguasa lagi, ia tidak lagi berada di pusat diskursusnya; segala sesuatu senantiasa berfungsi sendirian dan diskurus pun terus mengartikulasikan dirinya sendiri, namun 'di luar subjek'. Dan tempat ini, 'di luar subjek' ini, persis adalah apa yang disebut dengan ketaksadaran (Bracher, 2009).

Memahami karya sastra menggunakan perspektif Lacan ialah memahami karya sastra dengan usaha untuk menemukan ketidaksadaran subjek dalam mencari keutuhan atau kepenuhan dirinya. Akan tetapi, kondisi ketidaksadaran itu tidak mungkin dapat diakses sepenuhnya. Oleh karena itu, untuk dapat memahami karya sastra tersebut cara yang dilakukan ialah dengan melihat bahasa karya sastra tersebut, yaitu melalui fenomena metafora dan metonimia (Faruk, 2012). Perhatikan bait berikut.
Aku memang benar tolol ketika itu, mau pula membikin hubungan dengan kau; lupa kelasi tiba-tiba bisa sendiri di laut pilu, berujuk kembali dengan tujuan biru.
(Anwar, 2011)

Pada bait tersebut, 'aku' merasakan kehilangan, ketidakpuasan, atau kesia-siaan. Hal itu terjadi karena 'aku' tidak melakukan negasi terhadap 'kau". 'Aku' bertindak berdasarkan ketergantungan keinginannya pada keinginan orang lain-"kau"-dan keberadaanya menjadi penanda keinginan tersebut. Dalam hal ini, 'aku' bukan sebagai pusat dari diri dirinya sendiri. Hal ini dikarenakan adanya subjek lain dalam dirinya dan itulah yang dinamakan dengan "ketaksadaran".

Hasrat yang dimiliki oleh 'aku' dapat dikatakan tergolong ke dalam tatanan hasrat anaklitik pasif, yaitu seseorang bisa berhasrat untuk menjadi hasrat orang lain atau dimiliki Liyan sebagai objek dari sumber kepuasan Liyan. Sebagaimana 'aku' yang bertindak disebabkan oleh ketergantungan keinginannya terhadap orang lain, yang dalam bahasan ini berhubungan dengan keinginan "kau".

Belakangan, 'aku' menyadari hasrat tersebut. Oleh karena itu, ia tidak mendapati identitas diri yang sebenarnya. Diri yang ia identifikasi ialah diri sebagaimana yang diinginkan oleh "kau". Akan tetapi, sebagaimana pendapat Lacan dalam (Faruk, 2012), orang memang tidak akan memperoleh citra dirinya yang stabil karena mengetahui dirinya melalui respon orang lain. Pemahaman terhadap respon tersebut dapat menyebabkan terjadinya misinterpretasi sehingga salah dalam mengenali diri sendiri.

Pada puisi berjudul "Aku", diri secara 
metaforik diibaratkan dengan serigala. Akan tetapi, serigala ialah binatang buas dan liar. Berdasarkan larik-larik pada puisi, di satu sisi ia adalah objek yang diburu, sedangkan di sisi yang lain ia adalah subjek yang melawan untuk menemukan dan mengidentifikasi dirinya sendiri. Ia memiliki hasrat membentak sekitarnya tanpa rasa takut dan gentar melalui "...aku akan lebih tidak peduli" dan "Aku mau hidup seribu tahun lagi".

\section{Nocturno}

Aku menyeru-tapi tidak satu suara membalas, hanya mati di beku udara. Dalam diriku terbujur keinginan juga tidak bernyawa.

(Anwar, 2011)

Lacan membahas hasrat dalam kaitannya dengan dua elemen korelatif, yaitu kebutuhan (need) dan tuntutan (demand). Kebutuhan dipahami sebagai kebutuhan biologis murni manusia, sedangkan tuntutan dipahami sebagai ujaran. Kebutuhan biologis memiliki kemungkinan untuk dipuaskan, sedangkan tuntutan tidaklah mungkin untuk selalu terpenuhi atau terpuaskan (Miller, 2004). Dalam puisi pendek yang berjudul "Nocturno" tersebut, dapat disimpulkan terjadi suatu bentuk tuntutan yang diharapkan 'aku' untuk menjamin terpenuhinya kebutuhan akan dirinya yang ia inginkan. Akan tetapi tuntutan tersebut tidak dapat terpenuhi atau mungkin memang tidak dapat terpenuhi atau terpuaskan. Pada lirik dikatakan "keinginan" tersebut "terbujur", keinginan yang tidak 'hidup', tidak memiliki gairah, atau memang senyatanya memang "keinginan" tersebut tidaklah ada. bait berikutnya mempertegas ketiadaan atau ketidak-hidupan "keinginan" tersebut dengan "tidak bernyawa".

Barangkali, 'aku' sebelumnya mengalami peralihan dari kebutuhan menjadi tuntutan ketika menyadari keterpisahannya dengan
Yang Lain. 'Aku' lalu mulai menyadari, bahwa dirinya tidaklah menyatu dengan Yang Lain tersebut, sehingga membuat 'aku' merasa kehilangan, kekurangan, dan ingin menyatu kembali dengan Yang Lain tersebut. Akan tetapi keinginan tersebut tidak terpenuhi, sehingga kehilangan dan kekurangan selalu menyertai 'aku'.

\section{Subjek dan Cermin Hasrat dalam Aku Ini Binatang Jalang}

Subjek dikemukakan oleh Lacan dalam teorinya berawal dari pandangannya bahwa manusia diwakili oleh bahasa, objek-objek khusus yang disebut dengan "kata-kata". Dalam hal ini istilah Lacan untuk "kata" tersebut ialah "penanda". Seseorang berbicara dan menulis bagi Lacan selalu mewujudkan diri melalui bahasa, yaitu dengan penanda-penanda. Kemudian, penanda-penanda tersebut merupakan satu-satunya cara subjek untuk dapat mewujudkan dirinya (Hill, 2002).

Selain subjek, dalam teorinya Lacan juga merumuskan tentang hasrat. Teori tentang hasrat ia rumuskan dalam The Four Fundamental Concepts of Psychoanalysis dengan berargumen bahwa hasrat merupakan interpretasi (Lacan, 1977). Lacan merumuskan bahwa dalam proses dialektika hasrat meliputi hasrat akan pengakuan dan negativitas manusia adalah perjuangan akan pengakuan itu. Manusia menyadari keberadaan dirinya ketika pertama kali ia menyebut dirinya (Aku), hal ini terjadi melalui hasrat ketika seseorang mengenali hasratnya sebagai dirinya, dan bahwa hasrat tersebut terlepas dari objeknya.

Berkaitan dengan hal tersebut, Miller berpendapat bahwa analisis Lacan bukanlah penerimaan tunggal yang harus dilabeli oleh subjek, tetapi realisasi dari kekurangan konstitutifnya sendiri. Kemudian, tempat kosong hasrat itulah yang ditempati dan diperlihatkan oleh analisis dengan memunculkan hubungan transferensial. Lacan kemudian meringkasnya dalam frasa "hasrat 
analis" (Miller, 1998).

Lacan mengemukakan bahwa budaya memainkan peranan tertentu dalam perubahan sosial atau dalam menolak perubahan. Kedua hal itu dilakukan dengan memanfaatkan hasrat. Berhubungan dengan hal itu, Lacan mengatakan bahwa individu tidak bisa terpisah dari masyarakat (Sarup, 2011). Dengan kata lain, subjek tidak bisa dipisahkan dari masyarakatnya karena masyarakat ada dalam diri setiap individu. Lacan kemudian menegaskan selama gejala kebudayaan berhasil menginterpelasi subjek, hal itu dilakukan dengan membangkitkan satu jenis hasrat atau dengan menjanjikan dipuaskannya satu hasrat tertentu (Bracher, 2009). Lebih lanjut Lacan mengemukakan agar bisa memahami bagaimana suatu gejala kebudayaan bisa memengaruhi manusia, maka yang menjadi pusat perhatian dalam hal ini ialah hasrat, bukan pengetahuan.

Lacan membedakan tiga ambiguitas mengenai hasrat. Pertama, 'hasrat' bisa berbentuk sebagai hasrat untuk menjadi atau hasrat untuk memiliki. Kedua, Liyan bisa menjadi subjek atau objek hasrat. Ketiga, 'Liyan' bisa berupa citra orang lain yang ada dalam tatanan imajiner, atau kode yang membentuk tatanan Simbolik. Masingmasing objek hasrat dalam ketiga tatanan tersebut ialah citra, penanda, dan contoh objek ajaib atau substansi khusus yang disebut Lacan sebagai objek $a$.

Berdasarkan penjelasan tersebut, sebagaimana yang telah dikemukakan sebelumnya, Lacan mengemukakan empat bentuk hasrat dalam setiap tatanan, yaitu hasrat narsistik pasif (seseorang bisa berhasrat untuk menjadi objek cinta dari Liyan-kekaguman, idealisasi, atau pengakuan), hasrat narsistik aktif (seseorang bisa berhasrat untuk menjadi Liyan), hasrat anaklitik aktif (seseorang bisa berhasrat untuk memiliki Liyan sebagai cara untuk mendapatkan kepuasan), dan hasrat anaklitik pasif (seseorang bisa berhasrat untuk menjadi hasrat orang lain atau dimiliki Liyan sebagai objek dari sumber kepuasan Liyan) (Bracher, 2009).

Subjek 'aku' pada kumpulan sajak Aku Ini Binatang Jalang dapat disebut sebagai subjek yang eksis dalam tatanan Simbolik. Ia sebagai "aku" hadir dan ada dengan diri dan pikiranpikirannya. Pada beberapa puisi, 'aku' menjadi ada bukan karena yang lain (liyan). 'Aku' adakalanya juga berhasrat untuk menjadi Liyan (dapat berupa pemilik aturan, hukum, dan budaya dalam tatanan Simbolik). Selain itu, adakalanya pula 'aku' menyadari bahwa Liyan merupakan tatanan yang tertinggi akan tetapi dengan itu 'aku' justru merasakan kekurangan atau ketidakpuasan. Perhatikan kutipan puisi berikut ini.
Kesabaran
Aku hendak berbicara
Suaraku hilang, tenaga terbang
Sudah! tidak jadi apa-apa!
Ini dunia enggan disapa, ambil perduli
Keras membeku air kali
Dan hidup bukan hidup lagi
(Anwar, 2011)

Kekurangan dan ketidakpuasan 'aku' terhadap tatanan Simbolik dapat dipahami ketika ia "hendak berbicara". Akan tetapi ia berada dalam ketidakmampuan dikarenakan ketiadaan seperti: "suara yang hilang" dan "tenaga yang terbang”. Dunia bagi 'aku' merupakan tatanan tertinggi, akan tetapi dunia tersebut "enggan disapa". Dunia dalam pandangan 'aku' berada dalam keangkuhan, dengan begitu 'aku' memilih untuk tidak memedulikannya atau tidak menghiraukannya. Hal itu disebabkan karena 'aku' menyadari bahwa kehidupan dalam "dunia" tersebut "keras membeku". Pada puisi tersebut, 'aku' menolak untuk menyatu dengan Liyan dan tidak tunduk pada aturan Liyan.

Cermin hasrat serupa itu juga dapat dilihat melalui puisi yang berjudul "Selamat Tinggal". 
'Aku' digambarkan menjadi 'ada' dengan memilih meninggalkan "Perempuan" dan kembali kepada yang Riil. "Perempuan" dalam hal ini dapat dikatakan sebagai Liyan yang menyebabkan adanya "Luka" pada dirinya. Oleh sebab itulah, bagaimanapun munculnya seruan atau rayuan untuk kembali kepada Liyan tersebut, 'aku' memilih untuk tidak menghiraukan dan menganggap bujukan tersebut sebagai "angin lalu". Melalui penanda "menebal" dan "mengental", 'aku' menguatkan hasrat yang ia miliki untuk meninggalkan Liyan (perempuan) tersebut.

\author{
Perempuan \\ Aku berkaca \\ Ini muka penuh luka \\ Siapa punya? \\ Kudengar seru menderu \\ ? dalam hatiku? - \\ Apa hanya angin lalu?
}

Segala menebal, segala mengental

Segala tak kukenal

Selamat tinggal ....!!!

(Anwar, 2011)

Akan tetapi, upaya 'aku' seperti demikian bertolak belakang jika diperhatikan pada puisi yang berjudul "Do'a” berikut ini.

Tuhanku

Dalam termangu

Aku masih menyebut nama-Mu

Biar susah sungguh

mengingat Kau penuh seluruh

Caya-Mu panas suci

tinggal kerdip lilin di kelam sunyi

Tuhanku

Aku hilang bentuk

remuk

Tuhanku

aku mengembara di negeri asing

Tuhanku

di pintu-Mu aku mengetuk

aku tidak bisa berpaling

(Anwar, 2011)

Pada beberapa puisi yang telah dibahas sebelumnya, 'aku' cenderung mengidentifikasi diri sebagai subjek yang melakukan negasi atau penyangkalan terhadap yang lain (liyan) atau tatanan Simbolik yang melingkupinya. Negasi tersebut berlangsung dikarenakan adanya penolakan dalam diri untuk menjadi seperti Liyan atau tunduk pada aturan Liyan. Akan tetapi, negasi seperti demikian sama sekali tidak terdeteksi di dalam puisi "Do'a" tersebut. "Aku" tampak sepenuhnya tunduk pada aturan Liyan.

Pada puisi tersebut, hasrat yang dimiliki oleh 'aku' dapat digolongkan ke dalam hasrat narsistik pasif, yaitu seseorang bisa berhasrat untuk menjadi objek cinta dari Liyan. Berbeda dengan puisi-puisi sebelumnya, penandapenanda yang dihadirkan dalam puisi "Do'a" tersebut menjadi cara bagi subjek untuk mewujudkan dirinya. Dalam keadaan bagaimana pun dan seperti apa pun, misalnya "termangu", "susah", "hilang bentuk", "remuk", "mengembara”, subjek "aku” tidak bisa untuk tidak menyebut, tidak mengingat, atau berpaling dari Tuhannya. Ia menghendaki diri untuk selalu dikasihani oleh Tuhan bagaimanapun lika-liku kehidupan yang ia jalani.

\section{Simpulan}

Berdasarkan pembahasan yang telah dilakukan, dalam beberapa puisi yang memiliki sudut pandang 'aku' lirik, cenderung ditemui subjek yang merasakan ketidakpuasan, kekecewaan, kesepian, dan penuh pertanyaan terhadap berbagai hal yang dalam pembahasan ini dapat digolongkan sebagai Liyan. Berhubungan dengan hal itu maka tidaklah keliru jika Maier mengatakan bahwa dalam sajak-sajak terakhir Chairil Anwar cenderung terdapat di dalamnya makna kenabian: keheningan dan kesepian. Oleh sebab itu, 'aku' lirik dalam hal ini memprakarsai kebebasan, keindividuan, atau ketidakterikatan.

Berdasarkan analisis yang telah dilakukan menggunakan psikoanalisis Lacan pada 
Poetika : Jurnal Ilmu Sastra

Vol. 8 No. 1, Juli 2020
DOI 10.22146/poetika.56534

ISSN 2338-5383 (print) ; 2503-4642 (online) kumpulan sajak Aku Ini Binatang Jalang karya Chairil Anwar, maka dapat disimpulkan bahwa 'aku' lirik merupakan subjek yang kurang atau terbelah. Meskipun begitu, 'aku' lirik berusaha untuk menjadi utuh di tatanan simbolik atau mengidentifikasi diri dengan cara memenuhi hasratnya melalui objek pengganti hasrat yang lain. 'Aku' lirik sebagai subjek cenderung mengidentifikasi diri sebagai subjek yang melakukan negasi atau penyangkalan terhadap Yang Lain (Liyan) atau tatanan Simbolik yang melingkupinya. Negasi tersebut berlangsung dikarenakan adanya penolakan dalam diri untuk menjadi seperti Liyan atau tunduk pada aturan Liyan. Dengan kata lain, 'aku' lirik cenderung merasakan ketidakpuasan, ketakutan, dan kesepian sehingga ia mengidentifikasi diri atau mengkonstruksi diri menjadi individu yang bebas, mandiri, dan tidak terikat.

\section{Daftar Pustaka}

Anwar, C. 2011. Aku Ini Binatang Jalang: Koleksi Sajak, 1942-1949. Jakarta: Gramedia Pustaka Utama.

Bracher, M. 2009. Jacques Lacan, Diskursus, dan Perubahan Sosial: Pengantar KritikBudaya Psikoanalisis. Yogyakarta: Jalasutra.

Chisaan, C. 2008. Lesbum: Strategi Politik Kebudayaan. Yogyakarta: LKIS Pelangi Aksara.

Dallmayr, F. 1989. "Freud, Nietzsche, Lacan: A discourse on critical theory". International Journal of Politics, Culture, and Society, 2(4), 467-492.

Faruk. 2012. Metode Penelitian Sastra: Sebuah Penjelajahan Awal. Yogyakarta: Pustaka Pelajar.

Gallop, J. 1984. "Lacan And Literature: A Case For Transference". Poetics, 13(4-5), 301-308.

Heny, A., \& Pujiharto. 2019. "Hasrat Sartika Sari Dalam Kumpulan Puisi Elegi Titi Gantung: Perspektif Psikoanalisis Lacanian". Atavisme, 2, 144-158. https://atavisme.kemdikbud.go.id/ index.php/atavisme/article/

view $/ 585 / 378$

Hill, P. 2002. Lacan Untuk Pemula. Yogyakarta: Kanisius.

Jassin, H. B. 1975. Gema Tanah Air Prosa dan Puisi 2. Jakarta: Balai Pustaka.

Jassin, H. B. 1985. Kesusastraan Indonesia di Masa Jepang. Jakarta: Balai Pustaka.

Lacan, J. 1977. The Seminar of Jacques Lacan, Book XI: The Four Fundamental Concepts of Psychoanalysis. Trans. Alan Sheridan. New York: W. W. Norton \& Company.

Lacan, J. 1978. Seminar XI: The Four Fundamental Concepts of Psychoanalysis. New York: Norton.

Maier, H. M. J. 1987. "Chairil Anwar's "Heritage: The Fear of Stultification": Another Side of Modern Indonesian Literature". Indonesia, 43, 1-29. https:// doi.org/10.2307/3351207

Manik, R. A. 2016. "Hasrat Nano Riantiarno dalam Cermin Cinta: Kajian Psikoanalisis Lacanian". Jurnal Demo, 27(1), 31-39.

Miller, J. A. 2004. "Introduction to reading Jacques Lacan's seminar on anxiety". Lacanian Ink, 26, 6-67.

Miller, P. A. 1998. "The classical roots of poststructuralism: Lacan, Derrida, and Foucault". International Journal of the Classical Tradition, 5(2), 204-225.

Muller, J. P. 1980. "Psychosis and Mourning in Lacan's Hamlet". New Literary History. https://doi.org/10.2307/468811

Pluth, E. 2006. "Lacan's subversion of the subject". Continental Philosophy Review, 39 (3), 293-312.

Rosidi, A. 2018. Ikhtisar sejarah sastera Indonesia. Bandung: Dunia Pustaka Jaya.

Sarup, M. 2011. Panduan Pengantar Untuk Memahami Postrukturalisme dan Posmodernisme. Terj. Medhy Aginta Hidayat. Yogyakarta: Jalasutra.

Suyono, S. J. 2016. Chairil Anwar: Bagimu Negeri Menyediakan Api. Jakarta: Kepustakaan Populer Gramedia bekerja sama dengan Tempo Publishing. 